\title{
Marxism, Maoism, and Social Change
}

\author{
ANDREW G. WALDER \\ Universily of Michigan
}

The strategy and thought of Mao Ze-dong, judging by the sheer volume of writing devoted to it, appears to have been subjected to the most thorough analysis by students of China. This work has most often compared Mao with both the "orthodox" Marxist tradition and traditional Chinese thought. Mao's conceptions have been closely compared with those of Lenin, Stalin, and Trotsky (Schwartz, 1951; Meisner, 1967; Schram and d'Encausse, 1969; Schram, 1971; Starr, 1971); with Gramsci, Lukacs, Korsch, Marcuse, and a host of lesser Marxist figures (Wakeman, 1973); with Russian Populists (Meisner, 1971); with the intellectual traditions of China (Meisner, 1967; Wakeman, 1973); and with Kant, Hegel, and a corps of obscure Kantian

AUTHOR'S NOTE: $I$ awe a debt of gratitude 10 Donald $J$. Munro and Richard $M$. Pfeffer, both of whom helped me to develop and shape the ideas in this essay. I am especially grateful to the former for his consistent encouragement and to the latter for his unusually thorough and helpful criticisms of an earlier version. Any remaining shortcomings are, along with the opinions expressed herein, my own responsibility.

EDITOR'S NOTE: This is Part A of a two-part article. Part B will be published in the April 1977 issue.

MODERN CHINA, Vol. 3 No. 1, January 1977

- 1977 Sage Publications, Inc. 
and neo-Hegelian philosophers (Wakeman, 1973). Mao's originality as a Marxist thinker has been attacked (Wittfogel, 1960), defended (Schwartz, 1960), and carefully qualified (Schram, 1967, 1971). An impressive breadth of factual knowledge about the Leninist tradition and traditional Chinese thought has characterized these efforts to gauge Mao's position within the Marxist tradition and trace the many influences upon him from without it. Yet, surprisingly, analysis of the writings of Marx himself has played only a minor, vestigial role in these studies. Schram and d'Encausse's Marxism and Asia, for example, devotes only ten pages of analysis to Marx's own writings, based almost wholly on isolated quotes extracted from letters and articles on colonialism. Even Wakeman's formidable History and Will, which contains the most comprehensive treatment of Marx's theoretical writings in this literature, deals with them in just over twenty widely scattered passages, largely comprised of passing references and assertions about what Marx was supposed to have said. Nowhere in these two works or in any of the other cited literature is Marx himself given the attention devoted to Lenin, Trotsky, or even Friedrich Paulsen or Kang You-wei.

This relative paucity of at least observable research into Marx's own writings has in no way prevented these writers from assessing Mao's relationship to Marx and the Marxist tradition. A dominant theme presents Leninism as a degeneration from original Marxism, and Maoism, in turn, as a further degeneration from Leninism (Pfeffer, 1976). A related, recurrent theme presents Mao as a "voluntarist" compared with an allegedly more "economic determinist" Marx. Mao, we are repeatedly told, displays "activistic and voluntaristic impulses" (Meisner, 1967: 266), a "Rousseauan-Jacobin voluntarism diffused through Marxism-Leninism" (Goldman, 1973: 246), and "extreme voluntarism" (Schram, 1969: 135). Not surprisingly, the Great Leap Forward is described as "when Mao and his comrades indulged in the greatest orgy of voluntarist thinking in the history of the communist movement" (Schram, 1967: 160). This type of "voluntarism" has at times been sug- 
gested to be so extreme that it represents a break with "the very essence of Marxism" and is characteristic of "a revolution which has nothing in common with Marxism" (Schram and d'Encausse, 1969: 110, 112).

PREVIOUS TREATMENTS

OF MAO'S "VOLUNTARISM"

"Voluntarism"-in this case denoting a social analysis and revolutionary strategy stressing human will as the primary causative agent in producing desired social change-is thus a commonly accepted characterization of Mao's thought. ${ }^{1}$ In the China field the term "voluntarism" is used in two distinct but integrally related senses. The first refers to the relative emphasis Mao places on subjective human effort in activist politics over objective economic forces to produce social change. In this sense Mao is said to have inverted Marx's dialectic, so that in his method of analysis "superstructure" rather than "economic base" is the primary, if not sole, factor. Closely related to this first sense is the second-Mao's conception of stages of revolution and the emphasis he places on activist politics to speed, even "telescope" the succession of these stages in Chinese society. In this second sense Mao's approach is contrasted with a Marx who allegedly laid out a conception of clearly demarcated and "objectively determined" stages of world history with specific roles prescribed to each social class in every specific stage. Mao's voluntarism in this second sense-that of the speeding of stages through emphasis on politics - is viewed by Schram as closely linked to Mao's voluntarism in the first sense - that of emphasis on the superstructural and human in his method of analyzing and changing society:

the primacy of politics and the human factor ... are linked and constitute two aspects of the voluntarism that Mao Tse-tung [Mao Ze-dong] inherited from Lenin and has carried one step further, in a context in which reliance on the economic determinism of orthodox Marxism for the accomplishment of the hopedfor revolution was even less possible than in the Russia of 1917. [Schram, 1969: 266] 
So Mao, faced with a situation in which the "economic determinism of orthodox Marxism" was of no use, went even further than Lenin in speeding the stages of history despite the lack of economic development that Marx allegedly saw as a necessary precondition for socialist revolution. Mao, after dispensing almost totally with Marx's "economic determinism," we are told, developed a voluntaristic method of analysis and strategy for social change that placed near-total emphasis on human will as the primary causative agent, making the superstructure rather than the economic base the key category of analysis.

Meisner, who with Schram has been one of Mao's foremost interpreters in the China field, agrees with this twofold conception of Mao's voluntarism. For Meisner, what he refers to as the "socialist faith" of both Mao and his teacher $\mathrm{Li}$ Da-zhao

was ultimately based not upon confidence in the workings of the objective laws of socialist development, but rather upon confidence in their abilities to bring forth powerful subjective forces latent in the present - the great storehouses of "surplus energy" that $\mathrm{Li}$ argued had been accumulating in China over the centuries. The ideas, wills, and the "self-consciousness" of man would really determine the course of Chinese history. [Meisner, 1967: 266]

After noting this, the first sense of Mao's voluntarism, Meisner links it with the second:

These notions reflected not only the voluntarist's impatience with the economic forces of history and his impulse to carry out the proletarian revolution, even without the actual proletariat if need be, but also the willingness of the Chinese nationalist to abandon the only progressive social class in Chinese society ... and to look to broader, "national" sources of revolution. [Meisner, 1967: 267] ${ }^{2}$

With Mao's apparent voluntarism enjoying such a solid consensus, the only task left is to retrace its intellectual origins. Wakeman's cerebral History and Will seeks to do precisely this. Wakeman traces the early influences on Mao-Wang Yangming's concept of praxis as developing the world to develop the 
self; neo-Kantianism's concept of reason creating social forms that liberate the self from customs; Darwin's notion of objective laws of evolutionary change; and T. H. Green's glorification of will and his depiction of society as the instrument of individual self-realization, among many others. "Those earlier reflections," Wakeman (1973: 294) concludes, "allowed Mao a commitment to continuous and unending historical change that was far more extreme than Marx's own." This is, in part, the case because Mao's "variant of Jacobinism" has "salvationist roots" - "the Confucian gentleman's duty to renovate the people" (Wakeman, 1973: 63).

CONCEPTUAL FOUNDATIONS OF

THE FIRST ASPECT OF MAO'S "VOLUNTARISM"

This almost universal conception of Mao as a voluntarist is closely related to the manner in which the issue of "determinism" versus "voluntarism" is conceived in the China field. The very terms and categories these scholars use to think about and discuss the dialectical modes of analysis of both Marx and Mao preclude an accurate conception of the analytical method of either thinker. Instead of conceiving in a dialectical fashion, as did Marx, of superstructure and economic base as merely different aspects or sides of a single unit or conceptual structure, these writers without exception resort to the atomistic conceptions of our own Western philosophical and scientific traditions. Superstructure and economic base are instead considered, in the fashion of the dominant positivistic social sciences, as distinct, separable factors or independent variables reacting on one another. With Marx's method of analysis conceived of in this fashion, it is virtually impossible to accurately interpret the thought of either Marx or Mao.

Without Marx's analytical method of a single conceptual structure containing opposing and dialectically interrelated aspects, the authors are forced to rely on a series of oversimplified dualities in order to talk about Marx and evaluate Mao. Issues are cast in terms of "voluntarism versus determinism," 
"superstructure versus base," and "human will versus objective economic forces," despite the fact that Marx never conceived of these terms as distinct, separable factors. However the issue is characterized, these authors universally present a series of either/or choices as opposite ends of an imaginary spectrum. The whole effort becomes merely one of choosing which end of the duality each thinker is "closer" to. For Meisner the choice is between, variously, "social superstructure" and "economic base" (1965: 168); "political factors" or "economic factors" (1965: 168); "ideas" or "material forces" (1965: 168); "the choices and actions of men" or "the inexorable movement of material forces" (1971: 6); and the "ethically desirable and humanly possible" and the "historically predetermined" (1971: 7). Schram's formulation of the same problem differs only verbally. For him the issue is a choice between "human will" and "objective reality" (Schram and d'Encausse, 1969: 108); and "voluntarism" and "an utterly deterministic force majeure" (Schram, 1967: 160). Even when scholars have taken rare exception to the characterization of Maoism as voluntarism, they have remained entrapped within this dualistic conception. For this reason, Holubnychy $(1964 ; 1965)$ can only assert the exact opposite from Schram and Meisner - that Mao is, like Marx, "utterly deterministic," rather than a voluntarist like Stalin. For him the choice is between "man's will" and "objective laws."

With the issue thus formulated as a choice between clearly opposite and separate poles, there could be no middle ground between the Schram/Meisner and the Holubnychy positionsit was necessary to emphasize one end of the voluntarism/determinism duality or the other. This choice, based on a misconceived distinction between superstructure and economic base, is at the root of the failure of Holubnychy and Schram to develop a scholarly dialogue - there was no basis for communication. To Schram, who focused on Mao's distinctive mass campaigns, Mao was obviously an "extreme voluntarist"; to Holubnychy, who focused upon Mao's concept of practice, Mao was "utterly deterministic," since he asserts, as did Marx, that human consciousness is firmly rooted in the material process of production. 
Within this dualistic, either/or framework there was simply no way to incorporate the insights of each writer into a coherent, complete portrait of Mao. Schram, as a result, could do little more than curtly declare Holubnychy's conception "ironic" in the light of the obvious extreme voluntarism of the Great Leap Forward (Schram, 1967: 159-160), while Holubnychy, on the other hand, could only vent his wrath on Schram and the China field for being "purely" ideological (Holubnychy, 1965: 190). None of these writers, apparently, could conceive of Mao as being neither a "determinist" nor a "voluntarist." There is simply no way, in their conception, to reconcile seemingly voluntaristic and deterministic aspects of Mao's thought.

Interpreters of Mao, since they conceived of the issues in these dualistic, either/or terms, with superstructure and base as clearly separate factors, found themselves in a difficult position when trying to explain Marx's obvious acknowledgment of "human activity" as an important aspect of the development of history. As virtually all of Mao's interpreters recognize, Marx in no way precluded ideas, laws, and other aspects of the superstructure from playing an important role in human history. A complex problem thus presented itself-if Marx designated an active role to the superstructure, how could his approach possibly be distinguished from Mao's? The solution to this problem was the only one that could be afforded by a conception of superstructure and base as separate factors - an exceedingly vague, contradictory, and formless relativism.

Marx, instead of being presented as a thinker with a complex, coherent conception of the relationship between superstructure and base, is portrayed as a thinker with unspecified, contradictory "strains" in his thought - "voluntaristic elements" and “deterministic elements" (Schram and d'Encausse, 1969: 110). This presentation of Marx is made plausible by pulling ambiguous, isolated quotes from widely different sources and, not surprisingly, declaring them "fragmentary and inconclusive" (Schram and d'Encausse, 1969: 9-15). Since Marx's thought allegedly contains both "voluntaristic and deterministic elements," we are asked to believe that Marx is an economic 
determinist, but that " 'voluntarism' is by no means absent from Marx himself" (Schram, 1969: 135). Marx, quite confusingly, must be an economic determinist who is "somewhat" of a voluntarist. Perhaps more confusing, such "orthodox" Marxists as Kautsky were "even more" deterministic than Marx, but still, Marx "tended to emphasize economic and social determinism" (Schram and d'Encausse, 1969: 17). Lenin, who lacked "patience" with Marx's "determinism," subsequently "shifted the accent from the determinist to the voluntarist strand in Marx's thought." If this concept of "shifting the accent" seems vague, Lenin's position is made no clearer when Schram qualifies even Lenin's own "voluntarism": "This does not mean, of course, that he believed there were no limits to the action of the revolutionaries; he always stressed the fact that one must adapt oneself to concrete revolutionary situations" (Schram and d'Encausse, 1969: 17). Schram's conception of the relationship between Marx and Lenin boils down to this: Marx was a determinist who was somewhat of a voluntarist; Lenin was a voluntarist who was somewhat of a determinist. The difference is merely one of "accent."

Since this complex problem of specifying the concrete differences between Marxists in their respective conceptions of superstructure/base relations has become merely a question of pegging each thinker into a continuum running from determinism to voluntarism, dealing with $\mathrm{Mao}$ is no real problem. All that is necessary is to assert, with characteristic vagueness, that "there is no doubt" that Lenin's voluntarism is carried "still further in Mao Tse-tung" (Schram, 1969: 135). This greater voluntarism is characterized by a "general shift in emphasis" from base to superstructure, where Mao now "tends" to see superstructure as the more important of the two (Meisner, 1965: 168-169). The Chinese may evoke the "deterministic formulas of Marx," but this is only a smoke screen-Mao's conception clearly reflects a "lack of confidence in the determining forces of history" (Meisner, 1965: 168-169). In such a conception, where thinkers can be distinguished only by the distance between them on the voluntarism/determinism spec- 
trum, it helps to accentuate the differences between thinkers to give this conception some semblance of concrete meaning. So the complex implications of Marx's own "voluntarism" are simply ignored, and Marx is characterized simply as a "determinist," while Mao, largely in order to be able to distinguish him from the voluntarist Lenin, must of necessity be labelled an "extreme" voluntarist (Schram, 1969: 135). It is remarkable that, aside from the relativistic jargon-Lenin "tends" to emphasize voluntaristic "strands" and so forth-there is simply very little discussion of the concrete substance of the differences in each thinker's treatment of actual superstructure/base relationships - such as the crucial one between material conditions and human consciousness. On such a foundation has been erected the whole edifice of studies labeling Mao a voluntarist.

\section{MARX'S "DETERMINISM"}

The case for Mao's voluntarism in this first sense-that of analytical method and revolutionary strategy - suffers from two substantial flaws. First, Mao's interpreters rely far too readily on vague assertions about Marx's "determinism" rather than on detailed, concrete analysis of the writings of Marx himself. The result is a systematic overstatement of the "relative" importance Marx placed on the economic base in generating social change, as well as a complete misstatement of the actual relationship Marx saw between this economic base and the superstructure. Second, once these assertions about Marx pass unchallenged, these writers proceed, in turn, to exaggerate Mao's reliance on superstructural and attitudinal change to transform Chinese society. The result is a caricature of both Marx and Mao, presenting Marx as an "economic determinist" and Mao as a "voluntarist" rife with Hegelian and Confucian influences.

Characteristic of these previous exaggerations of Marx's "determinism" is the cursory treatment of Marx's relationship with the so-called "orthodox Marxists" of the late nineteenth century. Schram, remember, clearly acknowledges that these 
"orthodox Marxists" were "even more" deterministic than Marx, but he merely sweeps this problem under the rug when he vaguely asserts that Marx still "tended to emphasize economic and social determinism"-whatever this means (Schram and d'Encausse, 1969: 17). This sort of obfuscation on complex issues is at the heart of the commonplace exaggeration of Marx's "determinism" by interpreters of Mao.

Ample evidence exists in the writings of both Marx and Engels to demonstrate that the differences between Marx and these turn-of-the-century "orthodox Marxists" were indeed great. Engels, Marx's closest collaborator and foremost interpreter, spent in the waning years of his life a significant amount of time correcting the common misinterpretations by these "orthodox Marxists" who systematically ignored the important role Marx attributed to all aspects of the superstructure. Engels constantly repeated to these "Marxists," who reduced Marx's method of analysis into a form of economic determinism, that although he and Marx had asserted, in opposition to German idealist philosophers, that all social life was firmly rooted in material life, this in no way meant that the "economic base" caused all social life. Elements of the superstructure, he incessantly repeated, continually react on one another and on the economic base itself. In a letter to Mehring on July 14, 1893, Engels attributed this common misperception to the fact that in such early polemics as The German Ideology, where he and Marx were refuting idealistic philosophical conceptions of "ideals" or of a "world-spirit" as the sole moving force of world history, emphasis was of necessity laid to the important links between mental and material life:

there is only one other point lacking, which, however Marx and I always failed to stress enough in our writings, and in regard to which we are all equally guilty. We all, that is to say, laid and were bound to lay the main emphasis at first on the derivation of political, juridical and other ideological notions, and of the actions arising through the medium of these notions, from basic economic facts. But in so doing we were found to neglect the formal side-the way in which these notions came about-for 
sake of the content. This has given our adversaries ample opportunity for misunderstanding. [Marx and Engels, 1942: 510-511]

The primary misunderstanding derived from their necessary stress on the link between the material and mental, Engels explained, was

the fatuous notion of the ideologists that because we deny an independent historical development to the various ideological spheres which play a part in history we also deny them any effect upon history. The basis of this is the common undialectical conception of cause and effect as rigidly opposite poles, the total disregarding of interaction; these gentlemen often almost deliberately forget that once an historic element has been brought into the world by other elements, ultimately by economic facts, it also reacts in its turn and may react on its environment and even on its own causes. [Marx and Engels, 1942: 512]

On the contrary, Engels explained, the "common undialectical conception" of a determinist interpretation systematically ignores the obvious importance of superstructural elements as a potentially independent source of social change. With reference to politics, an element of the superstructure, Engels wrote to Conrad Schmidt on October 27, 1890:

the new independent power, while having in the main to follow the movement of production, also, owing to its inward independence ... reacts in its turn upon the conditions and course of production. It is the interaction of two unequal forces: on the one hand the economic movement, on the other the new political power ... which, having once been established, is endowed with a movement of its own. [MarX and Engels, 1942: 480]

Engels nowhere stated more unequivocally Marx's position about the relationship between superstructure and economic base than in his now-famous letter to J. Bloch of September 22, 1890. Here Engels reminded Bloch that in the materialist conception of history, human material life was only the "ultimately" determining factor, in the sense that it profoundly shaped the superstructure in distinctive ways: 
More than this neither Marx nor I have ever asserted. If therefore somebody twists this into the statement that the economic element is the only determining one, he transforms it into a meaningless, abstract and absurd phrase. The economic situation is the basis, but the various elements of the superstructurepolitical forms of the class struggle and its consequences, constitutions established by the victorious class after a successful battle, etc. -forms of law -and then even the reflexes of all these actual struggles in the brains of the combatants: political, legal, philosophical theories, religious ideas and their further development into systems of dogma-also exercise their influence upon the course of the historical struggles and in many cases preponderate in determining their form. There is an interaction of all these elements. [Marx and Engels, 1942: 475]

Engels not only laid out as a general, abstract proposition that elements in the superstructure strongly influence the economic base in producing social change, he also gave specific examples to illustrate his points. He explained that state power, merely one element of the superstructure, crucially shaped the development of the economic base in three basic ways - it could encourage production, channel it into certain directions, or, through misguided policies, obstruct economic progress, with disastrous effects on both state and society (Marx and Engels, 1942: 481-482). This effect is accomplished through the use of another aspect of the superstructure - the state's laws and financial policies - "tariffs, free trade, good or bad fiscal system" (Marx and Engels, 1942: 481-482). The "cringing servility" of the German petty bourgeoisie, and their deference to princes and nobles, for example, permitted a legal situation that accounted for the "miserable economic position" of the German principalities from 1640 to 1830 (Marx and Engels, 1942: 517; 1955: 442).

Further, this reaction of superstructure on the economic base in no way precludes a conception of the superstructure as firmly rooted in the economic base. Insted, the proper relation between superstructure and base is a "dialectical unity" - a conception of a simultaneous shaping of base by superstructure and viceversa - a constant, dynamic process whereby superstructure and 
base shape each other into a coherent social structure. Indeed, as Engels had explained some $\mathbf{3 0}$ years earlier, the very fact that we recognize a relation in society implies that the two related aspects are reciprocally related: "The fact that it is a relation already implies that it has two aspects which are related to each other. Each of these aspects is examined separately; this reveals the nature of their mutual behavior, their reciprocal action" (Marx, 1971: 225-226). This complex relational conceptualization simply cannot be comprehended by resorting to the dualistic categories employed in the China field. It is not a question of "determinism" versus "voluntarism," still less of measuring the "relative accent" placed on either the superstructure or the economic base. It is absolutely vital, instead, to have a clear conception of the actual complex relations Marx saw between aspects of social reality. Without this conception we are reduced to a vague relativism that can only produce caricatures of the thinkers under consideration-precisely the approach so often used in previous efforts on Mao and Marx.

Engels provided clear examples of this elusive superstructure/ base relationship. Law, for example, a profession that grows out of the division of labor of society, is charged also with regulating that division of labor (Marx and Engels, 1955: 399-400). Indeed, it is impossible to maintain any division of labor in society without a system of laws with which to regulate it. A capitalist economic base generates a specific system of law - necessarily enshrining private property - which naturally, in turn, reacts on the economic base. Engels points out the sections in Capital on the working-day, where parliamentary legislation had a determining effect on the length of the working-day - which for Marx was an important determinant of surplus-value - as just such an example of this complex relationship between superstructure and base (Marx and Engels, 1955: 402). In the same manner, colonial wars, as the most violent form of political activity rooted in the economic life of capitalism, in turn have a strong effect on that economic base, as in "the case of the conquest and brutal destruction of economic resources" (Marx and Engels, 1955: 399). Engels quite clearly felt that "Political, juridical, philo- 
sophical, religious, literary, artistic, etc., development is based on economic development." But this conception in no way precludes their reaction upon the economic base. On the contrary:

all these react upon one another and also upon the economic base .... it is not, as people try here and there conveniently to imagine, that the economic position produces an automatic effect. Men make their history themselves, only in given surroundings which condition it and on the basis of actual relations already existing. [Marx and Engels, 1942: 517]

These assertions about the effect of elements of the superstructure in the course of history were not merely qualifications adopted by the elderly Engels to defend the contradictions within the besieged system of his late collaborator. Marx himself consistently asserted, both as a general proposition, and in specific examples, the effects of superstructural elements on the economic base. These assertions were not contradictory "voluntaristic strands" in Marx's thought but were integral parts of his dialectical method of analysis. When speaking of production, distribution, exchange, and consumption, for example, Marx declared that: "Mutual interaction takes place between the different moments. This [is] the case with every organic whole" (Marx, 1973: 100). This model of reciprocal interaction allows, indeed requires, the superstructure to influence the economic base - for the "mental" to affect the "material." So under certain circumstances, for Marx, "theory, too, becomes a material force once it seizes the masses" (Marx, 1970: 137). ${ }^{3}$ Reflecting this appreciation, when Marx set out to write about concrete historical events he attributed great importance to the role of politics, law, and even great leaders in contributing to social change. His Eighteenth Brumaire of Louis Bonaparte and Class Struggles in France, 1848-1850 - which were, in Engels' words, "Marx's first attempt, with the aid of his materialist conception; to explain a section of contemporary history from the given economic situation" (Marx, 1964: 9) -are replete with accounts of decisive political actions taken by governments, parties, and even indi- 
viduals, relatively independent of any immediate economic connection, in making history (Marx, 1964; Marx and Engels, 1968: 95-180).

Further, this role attributed to superstructure is not only evident in Marx's political writings, it is also consistently reiterated in the most theoretical of Marx's "economic" worksCapital. In Marx's treatment of the development of capitalism in Great Britain, for example, superstructural elements - the state and its laws and financial regulations - play decisive roles in the development or nondevelopment of productive forces. This is the very same development of productive forces, according to the interpretation of Marx as a determinist, that is supposed to be an inexorable, "objective" event, independent of "human will" (Schram and d'Encausse, 1969: 108). On the contrary, a crucial factor in the development of capitalism is the ability of a political entity to develop an effective system of national credit. The development of a system of national debt and the printing of banknotes as legal tender for commodities, for example, stimulated industrial growth both in the home country and in other nations toward which credit was extended (Marx, 1967: 754-756). This superstructural system of financial laws, Marx felt, was one important reason why capitalism developed where and when it did. Such a system accounted for the early mercantile prominence of Venice; Venetian credit, when extended to the Netherlands, stimulated its early capitalist growth; the Dutch system of credit, once developed, in turn stimulated Great Britain's capitalist industrialization. At the time he was writing Capital, Marx related, this process of stimulation through the system of credit and national debt was underway between Great Britain and the United States (Marx, 1967: 754-756). But not only did this superstructural system of financial laws have an influence on when and where capitalism developed, it also affected the pace of industrial growth. Marx felt that Great Britain's laws of protection and tariffs, coupled with the development of systems of national debt and taxation,

was an artificial means of manufacturing manufacturers, of expropriating independent labourers, of capitalizing the national 
means of production and subsistence, of forcibly abbreviating the transition from the medieval to the modern mode of production. [Marx, 1967: 756-757]

But if Marx was clearly not the determinist he has so often been portrayed to be, nevertheless it would be misleading to end the discussion of Marx's conception of superstructure and base here, after asserting, on the basis of a few passages, that Marx gave an important role to superstructural elements in producing social change. As the treatment of Marx in the China field illustrates, quotes can be readily found to support almost any position about what MarX was supposed to have said. It is vital, instead, to weave these passages into an alternative interpretation of Marx's method of analysis, specifying how he used his definitions and concepts in his dialectical method of analysis. Before we can even speak of the relative roles Marx attributed to economic base and superstructure in generating social change, it is necessary to understand how Marx used the concepts "superstructure" and "base" and to understand what he meant by the word "determine."

\section{NOTES}

1. The characterization of Mao as a voluntarist has not always been the subject of such broad consensus in the China field. Holubnychy's (1964) complex analysis of Mao's thought stressed that Mao's conception of dialectical materialism emphasizes the links between human consciousness and the material process of production-far more so than did Stalin, whom Holubnychy contrasts with Mao as an example of a voluntarist. The following year, in a review of three of Schram's early works (Holubnychy, 1965: 187-188), he objected strenuously to the labeling of Mao as an "extreme voluntarist." Schram's (1967: 159-160) cavalier dismissal of Holubnychy's objections marked the end of this brief exchange, which never really developed into an intellectual debate, and attests to the seriousness with which alternative interpretations have ever been considered in the China field.

2. This position contradicts Meisner's earlier, correct realization that there is no rigid conception of stages of world history in Marx against which to measure Mao's voluntarism (Meisner, 1965: 166). To assert, as Meisner does here, that Mao is a voluntarist because he sought to make revolution without the proletariat implies that Meisner accepts the view that there is a proper stage for socialist revolution and a proper social 
class to carry it out within this stage. Meisner apparently either has abandoned Marx as the baseline for measuring voluntarism or has ignored or revised his earlier interpretation of Marx's materialist conception of history.

3. Meisner (1965: 169), in a passage indicative of the common misunderstanding of Marx's method, cites a paraphrase of this quote from Marx in a Chinese journal as prima facie evidence that Maoists have completely abandoned Marx's "determinism."

\section{REFERENCES}

GOLDMAN, M. (1973) "The Chinese Communist Party's 'cultural revolution' of 1962-64," pp. 219-254 in Johnson (ed.) Ideology and Politics in Contemporary China. Seattle: Univ. of Washington Press.

HOLUBNYCHY, V. (1965) Book review. China Q. 21 (January-March): 185-190.

_-_ (1964) “Mao Tse-tung's materialist dialectics." China Q. 19 (July-September): 3-37.

MARX, K. (1973) Grundrisse. New York: Vintage.

- - (1971) A Contribution to a Critique of Political Economy. London: Lawrence and Wishart.

- - (1970) Critique of Hegers 'Philosophy of Right.' London: Cambridge Univ. Press. (1967) Capital, Volume 1: A Critical Analysis of Capitalist Production. New York: International Publishers.

- (1964) Class Struggles in France 1848-1850. New York: International Publishers.

- - and F. ENGELS (1970) The German Ideology, Part 1, with selections from Parts 2 and 3. New York: International Publishers.

- - (1968) Selected Works. New York: International Publishers.

- - (1955) Selected Correspondence. Moscow: Progress Publishers.

- - (1942) Selected Correspondence. New York: International Publishers.

MEISNER, M. (1971) "Leninism and Maoism: some populist perspectives on MarxismLeninism in China." China Q. 45 (January-March): 2-36.

- (1967) Li Ta-chao and the Origins of Chinese Marxism. Cambridge, Mass.: Harvard Univ. Press.

- $-(1965) ~ " \mathrm{Li} \mathrm{Ta-chao}$ and the Chinese communist treatment of the materialist conception of history." China Q. 24 (October-December): 141-169.

PFEFFER, R. (1976) "Mao and Marx in the Marxist-Leninist tradition: a critique of the 'China field" and a contribution to a preliminary reappraisal." Modern China 2 (October): $421-460$.

SCHRAM, S. (1971) "Mao Tse-tung and the theory of the permanent revolution, 1958-69." China Q. 46 (April-June): 221-244.

- - (1969) The Political Thought of Mao Tse-tung. New York: Praeger.

- - (1967) "A review article: Mao Tse-tung as Marxist dialectician." China Q. 29 (January-March): 155-165.

- - - and H. d'ENCAUSSE (1969) Marxism and Asia. London: Allen Lane.

SCH WARTZ, B. (1960) "The legend of the legend of Maoism." China Q. 2 (April-June): $35-42$. 
- (1951) Chinese Communism and the Rise of Mao. Cambridge, Mass.: Harvard Univ. Press.

STARR, J. (1971) "Conceptual foundations of Mao Tse-tung's theory of continuous revolution.” Asian Survey 11 (June): 610-628.

WAKEMAN, F. (1973) History and Will: Philosophical Perspectives of Mao Tse-tung's Thought. Berkeley: Univ. of California Press.

WITTFOGEL, K. (1960) "The legend of Maoism" (in 2 parts). China Q. 1-2 (JanuaryMarch): 72-86; (April-June): 16-34.

Andrew G. Walder is currently in the Department of Sociology at the University of Michigan, where he is studying theories of organization and modernization and pursuing research on industrial organization in China. 